Archived version from NCDOCKS Institutional Repository http://libres.uncg.edu/ir/asu/

Schilbrack, Kevin. 2005. "Religion, models of, and reality: are we through with Geertz?" Journal Of The American Academy Of Religion 73, no. 2: 429-452. The version of record is available from Oxford University Press at http://www.oxfordjournals.org/en/.

\title{
Religion, Models Of, And Reality: Are We Through With Geertz?
}

\author{
Kevin Schilbrack
}

\begin{abstract}
Clifford Geertz's influential definition of religions as providing their members with both an ethos and a worldview-in his terms, both a "model for" and "model of" reality-has of late become a neuralgic point of contention in religious studies. In particular some critics have seen his ideas of religious models of reality as biased, out-moded, or in other ways confused about the way that language refers (or does not refer) to the world. In this article, I consider two criticisms of Geertz's project and seek to show that, despite the partial value of the criticisms, the idea of religious models of reality continues to be a legitimate and fruitful approach to what religious communities are typically up to.
\end{abstract}

IT IS A TELLING sign of the iconic status that Clifford Geertz has achieved that the same year in which one of his supporters complains that Geertz has been attacked "from the outset" and "from all sides," one of his critics complains that he is a darling of the humanities who continues to be read "uncritically" or even "piously" (Ortner: 1; Frankenberry and Penner 1999a: 617). This article seeks to avoid both extremes. On the one hand, Geertz's "Religion as a Cultural System" is now more than thirty years old, it is a legitimate object of criticism, and I find serious faults in it.1 On the other hand, I believe that one of Geertz's central theses—that religions provide their practitioners with "models of" reality, that is, symbolic conceptions of the general order of existencecontinues to be a fruitful way to understand an important aspect of religious beliefs and practices. My goal in this article is therefore to consider some widely read criticisms of this idea of religious models of reality, and to assess them.

In the first section of article I sketch Geertz's program. His definition of religion is well known but still sometimes misread, and I want to highlight how central to it is the idea not only that religions seek to conceptualize reality but also that they seek to conceptualize it as a whole. In the second and third sections of the article I consider two 
recent criticisms of Geertz's project. Talal Asad argues from a genealogical perspective that Geertz's treatment of religion as essentially a matter of meanings linked to ideas of general order is a tacitly Christian approach that hides the power relations that give rise to religion (27-54). And Nancy Frankenberry and Hans Penner argue from what they call a holist position that Geertz's account of religious symbol-making depends upon the now discredited idea of scheme-content dualism (1999a; reprinted, in 1999b). Both critics represent important perspectives unknown when Geertz published "Religion as a Cultural System" in 1966—namely, a genealogical approach learned from Michel Foucault and a holistic approach to meaning informed by Donald Davidson-and consequently both raise significant philosophical issues for Geertz's project and for the study of religion generally. I argue that neither undermines either the intelligibility of the idea of models of reality or its usefulness for the study of religion. In the final section I make some suggestions about how one might develop this feature of Geertz's approach.

\section{RELIGIOUS MODELS OF REALITY}

There are interpretations of religion that treat all the objects of religious belief as particular realities, analogous to the objects of science. Edward Tylor's theory of religion is a good example. On such accounts, religious beliefs and practices typically concern themselves with awe-inspiring objects or events, such as mountains, dreams, storms, or diseases. Other interpretations treat religion as also having a broader scope. These interpretations see one of the objects of religious belief and practice not as simply another particular thing or event but as a more inclusive reality or aspect of reality, such as the general order of existence, the nature of things, or that which is.

Geertz's interpretation of religion clearly falls in the latter camp. Geertz does have a place for religious claims about particular things- the over-sized mushroom or the falling granary-but on his account religions interpret such objects and events in the light of a system of symbols that functions to unite an ethos with a comprehensive worldview, which is to say, a way of life with a metaphysics. In other words Geertz holds that religion connects proper conduct not just to reality in the sense of "real things," but to the general order or nature of reality. For Geertz, this interest in metaphysics is a defining feature of religion, what distinguishes this cultural mode from others. For this reason one can refer to his approach as a metaphysical interpretation of religion.

By also including "ethos" in his definition of religion, Geertz holds that religions encourage certain feelings, attitudes, and experiences and seek to inculcate certain ritual, aesthetic, and ethical behavior. Religions consist in part of an ethos, therefore, in that they intend to mobilize people and to orient their lives. In Geertz's phrase an ethos provides a "model for" the world. This idea that religion is a "model for" reality is not uncommon in the study of religion. One sees parallels in Malinowski's concept of a charter, in Eliade's concept of a paradigm, and in Bruce Lincoln's concept of authoritativeness (Malinowski: esp. 108; Eliade: esp. 35-37; Lincoln: esp. 25-26). The claim that religion also consists of metaphysics is more contentious. By including metaphysics, Geertz claims that religion involves a theoretical or descriptive dimension 
by teaching some understanding of the most general context of human existence. In Geertz's phrase, religions provide "models of the world. It follows from this definition that, like science, religions seek to describe aspects of the world, though, unlike science, religions seek to describe not only contingent, empirical facts, but also "the very nature of reality" or "the way things in their sheer actuality are" $(1973: 128,127)$. In short, then, the notion of a religious metaphysics or a religious model of the world emphasizes that those who practice religions typically consider them true, whereas the notion of a religious ethos or model for the world emphasizes that religions are considered not merely true but also authoritative.

Daniel Pals has suggested that this interpretation of religion is obvious, "a kind of truism" (261). But clearly Geertz has opponents who disagree. Such disagreements, in my judgment, often reflect opposition to certain philosophical presuppositions that inform Geertz's theory. I will spend the rest of this section making explicit three of these presuppositions, with the hope that this will clarify why some of Geertz's more philosophically inclined opponents consider his theory-and specifically, the "models of" part of his theory-not obvious but superseded.

First, Geertz holds that religious traditions do not include a worldview simply because they are ontologically curious. Rather, they develop their ethos together with a metaphysics because they are interested in justifying their ethos, namely, by portraying that way of life as the proper way to live in the world. A religion's metaphysics is its attempt to legitimate its ethos.2 The way that Geertz puts this in his definition is that religions clothe their conceptions of the world with such an aura of factuality that the religious ethos seems uniquely realistic (1973: 90). Using the language of "clothes" and "auras" emphasizes the fact that religious traditions rarely seek to establish their teachings critically; typically they require practitioners to accept them on authority (1973: 109-10, 118). But this does not change the fact that religions presuppose that their teachings are not only theirs but also that they are true. That is, religions present their ways of life not as arbitrary but as wisdom: "Religion supports proper conduct by picturing a world in which such conduct is common sense" (1973: 129). On Geertz's definition, then, religions present themselves as warranted or justified, in the sense that religions offer an authoritative way of life by showing that the way of life is in fact authorized by the way things are.

What is presupposed here, then, is a certain philosophical anthropology. It is the view that human beings seek not only to live but to live in accord with the way the world actually is or, as Geertz often says, to live "realistically" (1973: 130). On this view people typically desire to ground their social practices, in some way or another, in reality. Geertz is explicit about this: "The need for such a metaphysical grounding for values seems to vary quite widely in intensity from culture to culture and from individual to individual, but the tendency to desire some sort of factual basis for one's commitments seems practically universal; mere conventionalism satisfies few people in any culture" (1973: 131). Now, a rival position also becomes clear, namely, those who believe that social practices have no foundation, that practices are so to speak where one's spade turns and that the way a culture lives can have no and needs no 
justification. Thus a metaphysical interpretation of religion like Geertz's is valuable to the extent that Geertz is right that religious practitioners are not satisfied merely by convention and claim that their beliefs and practices are warranted by the nature of things.

I turn now to a second philosophical presupposition. Though I have distinguished between worldview and ethos, as Geertz himself does, Geertz also says that religion fuses or synthesizes or even identifies world-view and ethos (e.g., 1973: 127). The relation between them is "circular" (1973: 141); they are "mere transpositions of one another" (1973: 118; cf. 94). In other words Geertz claims that religions typically teach that religious facts imply religious values and vice versa. Consequently, for Geertz, a single religious symbol (or system of symbols) like the Kingdom of God or the Dao can be read in both ways, as both model of and model for. In their studies of religious ethical cosmologies, Robin Lovin and Frank Reynolds have labeled the view that facts and values are connected, so that duties or obligations follow from how things are, "ethical naturalism" (Lovin and Reynolds 1985,1986,1992). If one adopts this label, one can say that, for Geertz, religious practitioners are typically ethical naturalists.3

Kenneth Rice has pointed out that "[i]f there is no such thing as a world view with no implications for one's style of life, or an ethos not based on some image of reality, then it seems somewhat inappropriate to speak of sacred symbols as 'synthesizing' ethos and world view" (82). Rice's point is that if they cannot be apart, then religions do not bring them together. This is right, though from the perspective of much modern philosophy the separability of worldview and ethos - of fact and value-is taken as a basic principle. By writing of "synthesis," therefore, Geertz underlines his view that in religions one finds together what much modern thought holds apart. Here again, a rival position becomes clear. There are many modern interpreters of religion who hold that to derive an ethos from the way things are, an "ought" from an "is," is fallacious. For this group, facts and values are not merely distinguishable (as world-view and ethos); they are separable. And from this perspective cultures could have or do have worldviews that involve no way to live, or they could or do have ways of life that involve no metaphysics. Thus Geertz's metaphysical approach is valuable to the extent that Geertz is right that religious practitioners feel that a powerfully coercive "ought" really does grow from a comprehensive factual "is" (1973: 126).

Third, Geertz presupposes that metaphysical claims are intelligible. Of course, many religious symbols concern non-metaphysical issues, but the important point is that Geertz holds that some religious symbols seek to refer to "the most general contexts of human existence," "the most comprehensive ideas of order," "the essential conditions in terms of which life must, of necessity, be lived" (1973: 126, 127, 129). If one believes that historically and culturally bounded people cannot aspire to knowledge of such matters, then one will have a very different approach to the study of religions. If metaphysics is impossible, then those religious practitioners who make such claims and those like Geertz who insist on attending to such claims offer nothing but mystification. "Religion as a Cultural System" opposes those who ignore metaphysical meanings and reduce religions to their social or psychological functions. Widespread when "Religion 
as a Cultural System" was written, such approaches to the study of religion held either implicitly or explicitly that religious metaphysics are meaningless and that one has exhausted what religious symbols mean once one has understood their social or psychological value. In that context Geertz complains that the "notion that religion tunes human actions to an envisaged cosmic order and projects images of cosmic order onto the plane of human experience is hardly novel. But it is hardly investigated either ..." (1973: 90). Against such views Geertz proposes the study of religion as a two-stage process: first, an analysis of the system of meanings embodied in the symbols which, he claims, reveals both an ethos and metaphysical worldview, and then, only after the native point of view had been established, should one relate these systems to socialstructural and psychological processes (1973: 125).

Today, Geertz's opponents are quite different. Since the sixties, a variety of movements have arisen that criticize the assumption that symbolic systems can reach outside themselves to connect to the world. These versions of postmodernism repudiate the possibility of metaphysical inquiry. In fact, for many contemporary philosophers, the issue whether metaphysics is intelligible is no longer a live question.4 It was answered long ago in the negative; what remains is but to identify and root out the residual metaphysics that others have not completely eliminated from their own antimetaphysical positions. Most Kantians, phenomenologists, deconstructionists, neopragmatists, and critical theorists would agree that metaphysics is unintelligible. In this context Jürgen Habermas can describe contemporary inquiry simply as postmetaphysical thinking (Habermas; for a critique of Habermas's antimetaphysical assumptions, Meyer). Thus Geertz's metaphysical approach is valuable to the extent that Geertz is right that religious metaphysical claims can be read as at least possibly true.

In my judgment, the view that religious practices typically involve commitment to some metaphysical model continues to be useful as an analytic tool (Schilbrack 2002a, 2004). In the contemporary context, however, Geertz's idea of a metaphysical interpretation of religions can seem not only not obvious but rather outmoded or naive. I turn now to two criticisms of Geertz, part of this antimetaphysical current, which seek to make this case.

\section{RELIGIOUS MODELS OF REALITY IN GENEALOGICAL PERSPECTIVE}

Talal Asad approaches the study of religion from a genealogical point of view. He wants to link the study of religions with an appreciation of their intrinsic connection to configurations of power. Because Geertz champions an interpretive social science in which the meaning of cultural processes is distinguished from their social and psychological causes and functions, he is, in my judgment, especially susceptible to such a critique. Nevertheless, Asad has a tendency to misrepresent Geertz's program, not least on the idea of religious models of reality, and thus, at least in this respect, his critique misses its target.

Asad's primary goal is to call into question the very idea of a universalist or essentialist definition of religion. Such a definition seeks to abstract from the varieties of particular 
cases what religion universally or essentially is, and Geertz's metaphysical interpretation is precisely such a definition. Asad argues that, far from being a truism, universalist definitions of religion are the product of certain post-Enlightenment discursive practices and that they reflect specifically Christian theological interests. Briefly, his genealogy is this. Medieval Christianity had been a life-shaping discipline that involved the courts, the schools, and the common institutional life of European society. But with changes in western culture, roughly, in the seventeenth century, such as the wars of religion, the increasing contact with Asian cultures and their religions, and the dramatic successes of the natural sciences in explaining the natural world, there arose a theological need for a scaled-back, lowest common denominator definition of religion. Asad traces this theological strategy to Edward Herbert's idea of a natural religion. It was Herbert who identified religion with belief, an inner mental state detached from ritual or political differences. By privatizing religion in this way, Herbert abstracted from "a concrete set of practical rules attached to specific processes of power and knowledge" the single, allegedly essential aspect of religion: what the individual believes. The modern understanding of religion is thus "a product of the only legitimate space allowed to Christianity by post-Enlightenment society, the right to individual belief " (Asad: 45 [emphasis in original]).

On this modern, truncated construction, religion is defined as "essentially cognitive," "as a set of propositions to which believers gave assent" (Asad: 44, 40-41). In such a context religion becomes a private matter, and the social, institutional, disciplinary ways in which religious belief is constituted are ignored. Asad repeats that this understanding of religion is theologically motivated. "It is preeminently the Christian church that has occupied itself with identifying, cultivating, and testing belief as a verbalizable inner condition of true religion" (48). Asad points to the following quote from Geertz as one in which one can see a covert theological motive. Geertz says that "What any particular religion affirms about the fundamental nature of reality may be obscure, shallow, or all too often perverse, but it must, if it is not to consist of the mere collection of received practices and conventional sentiments we usually refer to as moralism, affirm something" (1973: 98-99; Asad: 43). In this statement Geertz tries to distinguish religious from nonreligious practices by claiming that a religious practice is one that "affirms [something] about the fundamental nature of reality." The theological agenda comes into focus, Asad says, when one looks at the historical and social context from which this definition emerges. "The requirement of [a metaphysical] affirmation is apparently innocent and logical, but through it the entire field of evangelism was historically opened up, in particular the work of European missionaries in Asia, Africa, and Latin America. The unevangelized comes to be seen typically either as those who have practices but affirm nothing, in which meaning can be attributed to their practices (thus making them vulnerable), or as those who do affirm something (probably 'obscure, shallow, or perverse'), an affirmation that can therefore be dismissed" (Asad: 43).

A summary of Asad's critique can be approached, then, by highlighting two problems. Geertz's project treats religion as cognitive (thereby capitulating to the missionary's desire to show non-Christian religions as false), and he treats it as private (thereby divorcing it from the social practices that give them sense and authority). 
Thus, what appears to anthropologists today to be self-evident, namely that religion is essentially a matter of symbolic meanings linked to ideas of general order ... is in fact a view that has a specific Christian history Geertz's treatment of religious belief, which lies at the core of his conception of religion, is a modern, privatized Christian one because and to the extent that it emphasizes the priority of belief as a state of mind rather than as constituting activity in the world (Asad: $42,47)$.

As I suggested above, I believe that Asad's reading of Geertz is not as sharp as it might be. One place where it fits poorly is Asad's ambiguous claim that for Geertz, as for the modern study of religion generally, religion is "essentially cognitive," a mere assent to a set of propositions. If Asad means that for Geertz the essence of religion is cognitive belief and that the noncognitive aspects of religion are not essential, then he distorts Geertz's approach. In the first place, "belief is not even mentioned in Geertz's definition. Some of the earliest scholars of religion had such an intellectualist definition of religion, but they were criticized by those who argued that emotion or experience or duty was more central. Geertz clearly seeks not to return to belief or to any other of these single attributes but rather to gather different perspectives into a single, pluri-form one. Though one might rightly say belief is an essential part of a religion's worldview, the religion's ethos is equally essential to Geertz's definition. In fact, Geertz's examples of religious symbols-

[e]laborate initiation rites, as among the Australians; complex philosophical tales, as among the Maori; dramatic shamanistic exhibitions, as among the Eskimo; cruel human sacrifice rites, as among the Aztecs; obsessive curing ceremonies, as among the Navaho; large communal feasts, as among various Polynesian groups (1973: 132)

-are so focused on religious practices that one can understand how Geertz is able to say that culture is "not anybody's knowledge of or belief about anything" (1973: 12). In fact, diverting attention from belief is what Geertz says distinguishes his approach from what he calls "cognitive anthropology" (1973: 11).

If by "essentially cognitive," however, Asad means that Geertz's definition claims that in addition to the aesthetic, experiential, ritual, and ethical aspects of religion one will also necessarily find cognitive belief, then I agree that Geertz is guilty. But here is an irony. For it is precisely by insisting that one of the things that religions do is to make cognitive claims that Geertz distinguishes his approach from the modern study of religion. The study of religion after the Enlightenment is predominantly shaped by Kant's destruction of the traditional arguments for theistic religion's cognitive claims. As Kant closes the door to religion's appeal to theoretical reason, Asad is right that religion after the Enlightenment moved to a new "legitimate space," but it is primarily the space of noncognitive feeling or experience that one sees in Schleiermacher, Otto, and Eliade. The modernist strategy that Asad objects to, in which "religion" refers to a distinctive, nonreducible aspect of human life, has usually been made precisely by denying that 
religion makes cognitive claims about an intersubjective world. By insisting that religions are interested in teaching a worldview, Geertz's definition bucks the modernist trend.5

A second weakness in Asad's critique is his claim that for Geertz religion is an inner or private mental state. Asad bangs this drum loudly, but how are we to reconcile it with Geertz's statement that "the main source of theoretical muddlement in contemporary anthropology" is "the cognitivist fallacy" that culture consists of mental phenomena $(1973: 11,12)$ ? The truth is that Geertz carries into the social sciences the currents of a revolution in epistemology that takes meaning out of the head. 6 Consequently, he consistently attacks the idea that meanings are private. 7 "So far as culture patterns, that is, systems or complexes of symbols, are concerned, the generic trait which is of the first importance for us here is that they are extrinsic sources of information. By 'extrinsic,' I mean only that-unlike genes, for example - they lie outside the boundaries of the individual organism as such in that intersubjective world of common understandings into which all human individuals are born, in which they pursue their separate careers, and which they leave persisting behind them after they die" (1973: 92 [emphasis added]). Geertz's desire to drive this point home-that meaning is "objective," "visible, tangible, grasp-able," "as public as marriage and as observable as agriculture" (1973: 93, 444, 91) -is one of the most pervasive aspects of Geertz's program and a central part of the refiguration of social thought he announces (Geertz 1985: 165). Asad overlooks this. Perhaps he reasons that meanings are conceptions, conceptions are beliefs, and beliefs are inner mental states. But Geertz protests against precisely this assumption: meaning is not "a psychological phenomenon, a characteristic of someone's mind, personality, cognitive structure, or whatever" (1973: 13).8 In fact, Geertz's "dogged anti-psychological bias" is so pronounced that it might be listed as a fault (Shore: 24).

Geertz learned that meanings are public from a variety of sources. From pragmatists like Dewey he borrows the idea that "thought is conduct" (2000: 21-22). From hermeneutical phenomenologists like Ricoeur, he borrows the ideas of actions as texts, social semantics, and embodied meanings. Geertz's primary source, though, is the later Wittgenstein. Wittgenstein's "attack upon the idea of a private language, which brought thought out of its grotto in the head into the public square where one could look at it, his notion of a language game, $\ldots$ and his proposal of forms of life; $\ldots$ seem almost custom designed to enable the sort of anthropological study I, and others of my ilk, do" (2000: xii). 9 Religion is "the symbolic contrivances by means of which individuals imagined themselves as persons, as actors, sufferers, knowers, judges, as, to introduce the exposing phrase, participants in a form of life" (2000: 15). Geertz calls a form of life "the exposing phrase" precisely because it reveals his dependence on Wittgenstein. Given Geertz's insistence that meaning can only be interpreted in social practices, Asad's rhetorical question-"If religious symbols are understood, on the analogy with words, as vehicles of meaning, can such meanings be established independently of the form of life in which they are used?" (53)—is misplaced.

Where Asad is right, however, is that Geertz distinguishes religious meanings from social context. Precisely because he distinguishes between the analysis of symbols and 
connecting them to their social context, Geertz's studies in practice often fail to make it to the second stage. Religious meanings become divorced from social and political forces. An analogous criticism has been made of Geertz's treatment of political symbols (Shankman 1984, 1985). For example, Richard Franke complains, "Geertz's explanation of the coup d'etat and massacre of 1965-6 [in Java neglects] ... such key questions as who was killing whom, who benefited from the massacre, and how it might have changed rural class relations in Java. Instead of asking about the possible roles of and relations among elements such as foreign business interests, the United States $\mathrm{CIA}$, wealthy Indonesian military officers, and rural landlords, small holders and landless laborers in producing the coup and the massacre, about all of whom evidence is available, Geertz offers the 'goal [of] understanding how it is that every people gets the politics that they imagine."' In short, "interpretive theory ends up essentially denying the material, coercive side of the state, claiming that it is primarily a system of symbols" (Franke: 692). The same is true of his interpretive theory of religion: Geertz largely ignores religion's social or material aspects, treating it as a template that shapes people's lives but not vice versa. As others have complained, this leads to a static view of culture (Rice: 79; Karatheodoris).

Thus Asad's genealogical critique of Geertz is sometimes on target, sometimes off. But what about, specifically, the idea of religious models of reality?

Asad argues that the idea of religious models of reality is problematic. One problem that Asad notes (and which, I suspect, is widely shared by those who do not see the value of attention to religious metaphysics) is that most religious people seem to lack and to be uninterested in metaphysics. Because this is so, Asad argues, Geertz's definition confuses two levels of religious discourse. Quoting Geertz's claim that religious symbols both induce religious moods and motivations and also place them in a cosmic or metaphysical framework, Asad objects that these two processes are distinct.

Let us grant that religious dispositions are crucially dependent on certain religious symbols, that such symbols operate in a way integral to religious motivation and religious mood. Even so, the symbolic process by which the concepts of religious motivation and mood are placed within a "cosmic framework" is surely quite a different operation, and therefore the signs involved are quite different. Put another way, theological discourse is not identical with either moral attitudes or liturgical discourses-of which, among other things, theology speaks. ... [T] heological discourse does not necessarily induce religious dispositions, and . . . conversely, having religious dispositions does not necessarily depend on a clear-cut conception of the cosmic framework on the part of the religious actor. Discourse involved in practice is not the same as that involved in speaking about practice. It is a modern idea that a practitioner cannot know how to live religiously without being able to articulate that knowledge (36).

Asad is right that the two levels of discourse are distinct; the first order discourse of liturgy and profession of faith and the second order discourse of theology that takes 
liturgy and profession as its object reflect different goals. But it is hard to see that Geertz confuses them.

When Geertz speaks of metaphysics, he makes it clear that he does not mean by metaphysics some "clear-cut" or "articulate" reflection. In fact, he repeatedly says that religious metaphysics is usually not "of an explicit and consciously thought-about sort," "not consciously interpreted," and that worldview implicit in her rituals (1973: 127,128, 138). A religion's meta-physic is "most often, implicit [and] . . . reasoned articulateness ... is atypical" (1973: 90, 128). Geertz, like most anthropologists and historians of religion, ignores the doctrinal and scholastic aspects of religions. For example, to learn of the Oglala metaphysics, Geertz does not say that one must learn their theology nor even that one must buttonhole an elder; rather, one sees their circular worldview in their dances, paintings, and tipi arrangements. In the same way Javanese metaphysics is not found in a speculative text; instead, "perhaps the clearest and most direct insight" into Javanese metaphysics can be found by giving attention to their shadow-puppet plays (1973: 132). The problem here seems to be that Asad assumes a definition of metaphysics as a self-conscious mode of reflection typically practiced by intellectual elites. Asad is right that such "theological" discourse is not the same as liturgical discourse, but this narrow understanding of metaphysics is clearly not what Geertz is investigating.

As we have seen earlier, Asad also holds that to require religions to make metaphysical claims reveals a Christian agenda. The justification of evangelizing or colonizing with metaphysics is real; indeed, as I have argued, the justification of religious practices with metaphysics is what Geertz predicts. But to define religions as involving metaphysics is no more Christian than to define them as involving an ethos-or, for that matter, than to see religion, as Asad does, as involving politics. Though the terms "metaphysics," "ethos," and "politics" are all derived from the Greek and one might judge a particular religion as inadequate in terms of any of them, there is nothing necessarily invidious or crypto-Christian about the idea of a "religious metaphysics." Metaphysics is not necessarily an imperialist move. On the contrary, to take the opposite tack and to deny that religions may make affirmations about the world has been and continues to be a strategy-indeed, probably the most common strategy_for elevating the West over non-Christian cultures. The positivist tradition that holds that religions try but fail to speak of reality and instead produce nonsense or, at best, poetry is well known. From Auguste Comte's claim that the modern (western) world has passed out of religious and metaphysical stages to reach its present positive stage, to A. J. Ayer's elimination of theology and metaphysics as meaningless, and on to those who reduce religious myths and rituals to nothing but ideological mystifications, one sees the assumption that religious symbols cannot and do not refer to the world. Thus, on the question of religions as models of reality, it is again the anti-metaphysician, not Geertz, who capitulates to the dominant modern framework for understanding religions.

\section{RELIGIOUS MODELS OF REALITY IN HOLIST PERSPECTIVE}

Nancy Frankenberry and Hans Penner object to Geertz's theory of religion for a very different reason. They hold that Geertz's theory is involved in a tangle of conceptual 
problems because it presupposes certain discredited epistemological dogmas. These dogmas attempt to explain how language relates to the world but according to Frankenberry and Penner they have been undermined by Donald Davidson's important discussions of meaning, reference, and truth.10 At a time when the idea that the practices of describing, interpreting, and explaining religions carry philosophical assumptions has largely fallen out of discussion, Frankenberry and Penner's attention to such assumptions is especially welcome. Moreover, I judge both that they are right about the importance of Davidson's work for the study of religion and that Geertz is not wholly innocent of the problems they identify. Nevertheless, his approach is not tied to the dogmas in a necessary way, and in particular his idea of religious models of reality is not implicated in it.

According to Frankenberry and Penner, the problem with Geertz's theory stems from what Davidson calls scheme/content dualism (634-638).11 Scheme/content dualism is a view that seeks to divide thought into two parts: a conceptual system that our mind or our language provides and the preconceptual content that the world provides. A conceptual scheme serves to organize, shape, or give form to the otherwise uninterpreted, formless content of our thoughts. Davidson argues that the different ways of accounting for the relation between the scheme and the content are all unintelligible. For example, a conceptual scheme cannot organize the world (or "reality" or "nature") because to organize something implies that the something is plural. We can only organize distinct objects. As Davidson says, "[S]omeone who sets out to organize a closet organizes the things in it" (1984: 192). But distinct objects are already structured entities. They are not formless we-know-not-whats, waiting to be schematized by our minds or our language. Whether we speak of objects like knives and forks, cabbages and kings, or we speak of events like losing a button or stubbing a toe, as soon as the world falls under a description-or as Davidson likes to say, as soon as part of the world is "individuated"-it can no longer play the role of unconceptualized content. Because it is impossible to identify what is getting organized except in the terms of the conceptual scheme, the idea that a conceptual scheme "organizes" founders on the problem of identifying something without interpreting it. It founders, in other words, because it appeals to an idea of a "raw" or noumenal world that is otherwise uninterpreted or preconceptual or theory-neutral. To summarize, then, Davidson gives us good reasons why one cannot get outside one's beliefs and language in order to test whether those beliefs or that language corresponds to the way things are. In other words I read Davidson's "On the Very Idea" as an attack on the idea of noumena or the world as it is "in itself." I agree with Davidson that the very idea of a noumenal world that in principle cannot be described should fall out of philosophy altogether.

The collapse of scheme/content dualism has profound and as yet still unappreciated implications for the study of religion. This is because many approaches treat religions as conceptual schemes, the framework through which people experience the world (Godlove). This "framework model" of religion, however, presupposes the intelligibility of the problematic idea of experiential data that are not theory laden. Frankenberry and Penner's point is that the framework model infects Geertz's theory of religion. That is, they hold that Geertz treats religion as a conceptual scheme through which believers 
experience the world. Geertz assumes that religious symbols are intended to be representations that somehow picture or parallel or correspond to nonsymbolic entities.

Does Geertz treat religions as conceptual schemes? Three times Frankenberry and Penner point to the following quote as incriminating evidence: when one speaks of "models of" reality, Geertz says, "what is stressed is manipulation of symbolic structures so as to bring them, more or less closely, into parallel with the pre-established nonsymbolic system, as when we grasp how dams work by developing a theory of hydraulics or constructing a flow chart" (Geertz 1973: 93; cited in Frankenberry and Penner 1999a: 621, 622, and 624). In this quote, they say, Geertz assumes the unintelligible view that symbols somehow represent or correspond to the nonsymbolic, and this representationalism is central to the idea of religious models of reality.

Though I agree with Frankenberry and Penner's rejection of the framework model, it is important to recognize a legitimate use of the term "represent." Clearly there is an everyday and fully acceptable sense in which we speak of symbolic representations or models of reality. One can have, for example, a map of a city or a blueprint of a building. It makes perfect sense to say that a blue line on the map "corresponds" to this highway or that the construction workers "follow" or "copy" the blueprint. This makes sense, notwithstanding the fact that it involves a comparison between a symbol and something else "in the world" that is not symbolic. There is a game, then, in which this language is used.12 Why is it that such everyday cases are legitimate? It is because in them a symbol is not being compared to some prelinguistic or unconceptualiz-able noumenon but rather to a linguistically mediated, conceptualized, individuated element in reality. Blue line means highway; two squares mean French doors. In other words, though it is confused to argue that a conceptual scheme corresponds to unconceptualized reality, it is not at all confused to hold that words correspond to things. I would argue that this is Davidson's position as well; what is illegitimate according to Davidson is not the everyday idea that words or symbols can correspond to nonlinguistic or nonsymbolic entities but the epistemological idea that such correspondence is the definition of truth (Davidson 1996).

Does Geertz speak of "representation" in the illegitimate epistemological sense or in the legitimate everyday sense? Unfortunately, he seems to speak in both ways. Geertz sometimes sounds as if he thinks of religions as conceptual schemes, as lenses on otherwise uninterpreted world-stuff: he says things like religious symbols "provide a framework of general ideas in terms of which a wide range of experience-intellectual, emotional, moral—can be given meaningful form" and "[t]he drive to make sense out of experience, to give it form and order., is evidently as real and as pressing as the more familiar biological needs" (1973: 123, 140 [emphasis added]).13 This may sound like the framework model. Also, as Frankenberry and Penner point out, the fact that Geertz treats religion as a perspective, "a mode of seeing, ... a particular manner of construing the world," a perspective that contrasts with the commonsense, scientific, and aesthetic perspectives, similarly suggests that religion is one of many conceptual schemes. If these are examples of the framework model, then they are right that this is unacceptable. 
Yet when Geertz gives examples of his theory, they do not imply the framework model. For instance, the Azande who interprets the collapse of a granary as the result of witchcraft does not give order to an otherwise formless experience but rather (or "merely") orients herself to well-formed objects and events already in the world. The religious symbols do not give her the concepts of "granary" or "falling," but they tell her what to think and do about it; they add a layer of interpretation to an already interpreted situation. The same is true of the Christian who sees the Nazi movement against the background of The Fall and the Javanese who comes upon an unnaturally large mushroom. When Geertz gives these examples, what religion renders meaningful is not "the given," an uninterpreted we-know-not-what, as Frankenberry and Penner accuse (1999a: 636-638), but political movements, mushrooms, crop failures, or the death of children. In Geertz's examples, then, religious symbols point to linguistically mediated, already conceptualized aspects of reality and not to prelinguistic or nonconceptualized noumena. (In fact, this may be the very reason that Geertz uses the term "preestablished" in the allegedly offensive quote.) When Geertz is read in this way-that is, as a social scientist and not as a philosopher-religious symbols do not perform work that is significant from an epistemological point of view. They do not organize one's unconceptualized experience into concepts. They are, as Geertz himself says, simply "a gloss upon the mundane world" (124).

Terry Godlove makes a nice distinction that helps connect what I am calling the legitimate and illegitimate senses of "representation" to the study of religions. He distinguishes between the claim that religion has epistemic priority and that it has interpretive priority (Godlove: 109-110). On this account religious beliefs do not have, because they cannot intelligibly have, an "epistemic priority," in the sense of providing a framework or conceptual scheme through which a believer's world is organized. But they may have an "interpretive priority" for believers, in the sense that the religion's symbols can come to bear on their interpretation of all (or most) of the objects and events in their lives. Thus, insofar as Geertz's theory assumes that religious models of reality play epistemologically significant roles, ordering or organizing otherwise unordered experiential data, Frankenberry and Penner are quite right that it is seriously flawed. However, insofar as Geertz says that such models provide an interpretive gloss on the world, orienting and telling their members what to think, then this is not only not impossible, it happens every day.

It may be in order to close this ambiguity and to push Geertz's theory squarely into the problematic positions that Frankenberry and Penner develop another argument and, I judge, overstate their case. They argue that Geertz's theory of religion is actually a code for a theory of truth. They suggest, "Perhaps we can best make sense of Geertz's discussion of models of by thinking of it as an epithet for a correspondence theory of truth" (1999a: 622). They cite Davidson's arguments that correspondence theories are flawed. Then they suggest, "If he were to spell it out in terms of a theoretical concern with truth we suspect that models for would conform to what is known as a coherence theory of truth which places heavy emphasis on the internal consistency or coherence of a program, theory, or symbolic system" (1999a: 624). Coherence theories are also 
flawed, they say, because given coherence, there is no way to stave off skeptical worries that the world could be completely different from what we actually believe it to be (1999a: 624). In this way, Frankenberry and Penner argue not only that Geertz is a kind of closet epistemologist who is recommending flawed theories of truth but also that he tries to use two theories that contradict each other! I agree with Frankenberry and Penner that it is important to uncover the epistemological presuppositions in theories of religion. But here Frankenberry and Penner make little effort to show that their interpretation of Geertz resembles him; their discussion is larded with terms like "presumably," "perhaps," and "appears." Really, it seems that they are prosecuting a different agenda, namely, Davidson's understanding of truth, and Geertz is being made to stand in as a villain. It is a forced reading.

On my reading, then, Geertz's metaphysical interpretation of religion should drop the references to religion as a framework and thereby avoid Frankenberry and Penner's charge of "metaphysical scheming." On this account religious metaphysical symbols model reality, not in the sense that they seek to describe the character that reality has "in itself apart from all human conceptions but rather in the sense that they seek to describe the character that reality has "as such" or under all conditions. Religious "models of on this view are not inquiries into unconditioned reality but, as Geertz says, into the "conditions in terms of which life must, of necessity, be lived" (1973: 129).

One last wrinkle. If this interpretation of Geertz holds, then religious models of reality would seek to describe the fundamental features of reality, and such claims could be evaluated according to the criteria of metaphysics. Apparently, a reader suggested this interpretation to Frankenberry and Penner (1999a: 621 note). But they reject the idea that Geertz thinks that religions are trying to represent what really exists, because, they say, Geertz adopts "an 'as-if approach to religious belief.... Unfortunately, for Geertz it is the case that 'conceptions of a general order of existence' seek to impose fictions, not to describe the character and conditions of reality as such" (1999a: 631, 621 note). "The whole drift of Geertz's definition is toward the conclusion that religions urge upon us conceptions of a general order of existence that are fictional conceptions" (1999a: 639). As proof, they refer readers to Geertz's definition that religious symbols formulate a general order of existence and clothe these conceptions with an aura of factuality so that the religion's ethos seems uniquely realistic. Much is revealed, they claim, by Geertz's use of the word "seems." "This aura of factuality produces moods and motivations that seem uniquely realistic because they seem to correspond to secular life. In other words religious systems function as a model for reality when they are believed to be models of reality. But of course, this is a mistake, an illusion, a dream world!" (1999a: 639-640 [emphasis in original]).

If Frankenberry and Penner are right, then my metaphysical interpretation of Geertz's program is misguided. If they are right, then Geertz holds that a religion's worldview is not really a view of the world. To interpret religion as based on fictions would be incompatible with Geertz's claim that religions function to relieve the anxiety caused by real disorder and chaos in the world, but Frankenberry and Penner take this as a further sign of Geertz's confusion (1999a: 639). Here is my response. Frankenberry and 
Penner's discussion of religious "fictions" does lift up a term that Geertz himself uses. In his discussion of an interpretive theory of culture, Geertz says that anthropologists sometimes present their ethnographies as simply descriptions of natives' reality, but in fact both the anthropologist's account and the native's self-understanding are interpretations. This means that both are constructions that involve the selection of some information and the suppression of other information so that a narrative is created (1973: 16). "They are, thus, fictions; fictions in the sense that they are 'something made,' 'something fashioned'-the original meaning of fictio-not that they are false, unfactual, or merely 'as if thought experiments" (1973: 15 [emphasis added]). There still remains for Geertz "a difference of no mean importance," the question whether the interpretation is held to concern events that happened and actors that existed, or not. Insisting that even the native's understanding of reality is an interpretation, albeit an interpretation that alleges to be true, Geertz contrasts his approach with one in which "religion disintegrates into a collection of useful fictions" (1973: 121). So I conclude that here too Frankenberry and Penner misread Geertz's project. He does believe that religions typically involve a realist metaphysics that aims to describe the character and conditions of reality as such; on his understanding, a religion's worldview is meant to be a view of the world.

\section{CONCLUSION}

I have argued that Talal Asad is off target in his criticism that Geertz's approach treats religions as private or solely cognitive affairs. To understand religions as making affirmations about reality does not imply that religions are but inner mental states. I have argued that Asad is correct that Geertz tends to divorce religious meaning from its social context and to treat it as autonomous. This is a shortcoming of his work, but it does not impugn Geertz's metaphysical interpretation of religions. Similarly, I have argued that Frankenberry and Penner are on target in their denunciation of the framework model, though off target in their argument that Geertz's approach depends upon it. Geertz's idea that religions provide models of reality can be understood without introducing scheme-content dualism.

In my judgment this issue remains important because without a theory like Geertz's, scholars tend to approach religion as an aspect of culture unconnected to reality. Of course, religious people are liable to confusion, self-deception, and error, but it is not clear that a disconnect from reality should be built into the very definition of religion. Geertz's metaphysical interpretation of religion treats religion as a culture's attempt to articulate its most comprehensive view of reality but, as Asad points out, Geertz leaves open the possibility that its metaphysical beliefs are obscure, shallow, or perverse.

This value notwithstanding, one drawback of Geertz's terms is that they are so general. Geertz himself notes that "[t]he concepts used here, ethos and world view, are vague and imprecise; they are a kind of proto-theory, forerunners, it is to be. hoped, of a more adequate analytical framework" (1973: 141). If this article has been persuasive in its defense of a metaphysical interpretation of religions, then an appropriate next step would be to develop Geertz's concepts theoretically. For example, the concept of a 
religious ethos might be developed—at least in its moral aspect—by distinguishing along with Joel Kupperman between religious prescriptions that are "moral" and those that are "supramoral" (Kupperman: chap. 18). Religious moral prescriptions carry a strong appeal to social pressure, along with an incitement to the agent to feel guilty in the case of transgression. Examples include injunctions not to murder or steal. Religious supramoral prescriptions lack strong social pressure and incite feelings of regret and inadequacy rather than guilt. Examples include injunctions to have purity of heart, eliminate desires, or love one's neighbor. Both kinds of prescriptions would fall under the notion of a religious ethos as a model for reality, and especially as a model for selfhood, but distinguishing between them gives us terms with which to nuance different ethoi. One way in which the concept of a religious worldview might be developed is by distinguishing, along with Schubert Ogden, between metaphysics in the broad and strict senses (Ogden). Religious claims that are metaphysical in the broad sense aim to describe the features of human experience that are unavoidable or necessary; they seek to describe the character of human experience or subjectivity as such. Religious claims that are metaphysical in the strict sense aim to describe the features of experience as such that are unavoidable or necessary; they seek to describe the character of reality as such.14 Both senses of metaphysics fall under the notion of worldview but, again, they give us terms for understanding and identifying worldviews with greater precision.

In the end the most important issue is not whether Geertz remains as an icon in the study of religion. Eventually his works will no longer be read, and this is the way of all flesh. The more important issue is whether our theories of religion require us to see religious descriptions of the nature of the world as in principle confused or whether our theories permit us to see them, as Geertz recommends, as fallible but intelligible attempts to understand the world.15

\section{NOTES}

1 Two brief overviews of Geertz's work, including short but incisive critical comments, can be found in Bradd Shore and in Daniel Pals (chap. 7). A longer but uncritical account is Fred Inglis.

2 This is not to suggest that religions first have an ethos with its moods and motivations before it has a metaphysics or that the ethos has an explanatory priority over the worldview. For Geertz the two arise together and mutually support each other (1973: 126-127).

3 If one does accept this label, however, it is important to distinguish between ethical naturalism in the cognitivist sense intended here, in which ethical facts are natural facts that ethical thought discovers, and a widely used sense of the term "naturalism" that rejects metaphysics and tends to treat ethics as noncognitive. For Geertz the latter sense does not fit the way that religious practitioners typically understand their ethos. For a lucid discussion of naturalism in ethics, see Sturgeon. 
4 One egregious example is Joan Stambaugh's studies of Zen Buddhism. Stambaugh notes that Zen thinkers repeatedly make claims the scope of which includes "anything that is," "the elemental possibility of the existence of all things," or that without which nothing exists $(44,117,37)$. And Stambaugh quotes both Hee-Jin Kim and Toshihiko Izutso as saying that Zen involves metaphysics $(5,89)$. Nevertheless, Stambaugh insists that metaphysics is an inappropriate tool for understanding Zen thought because "metaphysics is dead." On her interpretation a Zen teacher like Dogen "refreshingly obviates meta-physics, trans-meta-physics, meta-meta-meta-physics and the whole business of'meta' of which it is to be fervently hoped we have truly had our philosophical fill" (16). But given the common Buddhist claim that whatever exists is characterized by suffering, impermanence, and emptiness (the three "marks of existence"), one has to wonder whether Buddhists really do not care to speak about the character of reality as such or whether Stambaugh's own commitment to overcoming a western tradition has blinded her to this interest.

5 The irony is even deeper, in fact, insofar as agreeing with modernity's critique of metaphysics is what makes postmoderns "most-moderns" (David Ray Griffin).

6 Geertz writes, for example, that "[t]he generalized attack on privacy theories of meaning is, since early Husserl and the later Wittgenstein, so much a part of modern thought that it need not be developed once more here. What is necessary is to see to it that the news of it reaches anthropology" (1973: 12), and "[everything from modern logic, computer technology, and cybernetics at one extreme to phenomenological criticism, psychohistory, and ordinary language philosophy at the other has conspired to undermine the notion that meaning is so radically 'in the head,' so deeply subjective, that it is incapable of being firmly grasped, much less analyzed" (1972: xi).

7 Typical statements include the following: "Culture ... does not exist in someone's head. ... Culture is public because meaning is. . . Cultural acts, the construction, apprehension, and utilization of symbolic forms, are social events like any other" (1973: $10,12,91)$.

8 Making the same point, Geertz insists that "[t]o undertake the study of cultural activity-activity in which symbolism forms the positive content-is thus not to abandon social analysis for a Platonic cave of shadows, to enter into a mentalistic world of introspective psychology or, worse, speculative philosophy, and wander there forever in a haze of "Cognitions," "Affections," "Conations," and other elusive entities" (1973: 19).

9 Geertz calls Wittgenstein the main figure making the shift from private to public investigation of meaning possible (2000: xi; cf. 12, 13, 17, 208n, 405n). Karatheodoris claims that "Religion as a Cultural System" predates Wittgenstein's influence on Geertz, though it may be only that the influence is there but not quoted.

10 Frankenberry and Penner cite Davidson (1984a, 1990) and their section titles make reference to Davidson (1984b, 1986). 
11 I argue for the significance of Davidson's philosophy of language to the study of religious beliefs in Schilbrack 2002b, from which this paragraph partially draws.

12 Frankenberry and Penner treat everyday examples as just as problematic as philosophical theories of truth. "What correspondence theorists require is an explanation of the presumed correspondence between the symbolic and the nonsymbolic. Just how do sets of symbols parallel, simulate, or imitate nonsymbolic reality? How does one obtain a conception of what a dam is by 'manipulating graphic or linguistic' sets of symbols? Is the blueprint or map accurate? Does the flowchart fit the facts? Is the symbolic representation an accurate description of the actual social system? Does the blueprint of the house match the actual house? Questions such as these have been the Achilles heel of all correspondence theories of truth, leading to their demise" (1999a: 622).

13 Similarly, Geertz says that "more than gloss, such beliefs are also a template" that not only interpret but also shape social and psychological processes (1973: 124); Balinese symbols "organize the world" (1980: 102); and anthropologists "see the lives of others through lenses of our own grinding and ... they look back on ours through ones of their own" (2000: 65).

14 Gamwell: chap. 4 develops Ogden's distinction as forms of transcendental argument, using the labels "transcendental hermeneutics" and "transcendental metaphysics." A distinction like this one is also implied in Robert Neville's distinction between religious ideas concerning the human condition and those concerning ultimate realities (Neville 2001a, 2001b).

15 This article has profited from thoughtful critiques by William L. Power, Phil Devenish, Matthew Bagger, and an anonymous reader for this journal, for which I am grateful. 


\section{REFERENCES}

Asad, Talal Genealogies of Religion: Discipline and Reasons of

1993 Power in Christianity and Islam. Baltimore: John Hopkins University Press.

Davidson, Donald "On the Very Idea of a Conceptual Scheme." In

1984a Inquiries into Truth and Interpretation, 183-198. Oxford: Clarendon Press.

1984b The Inscrutability of Reference." In Inquiries into Truth and Interpretation, 227-241. Oxford: Clarendon Press.

1986 “A Nice Derangement of Epitaphs." In Truth and Interpretation, 433-446. Ed. by Ernest LePore. Oxford: Basil Blackwell.

1990 "The Structure and Content of Truth." Journal of Philosophy 87/6: 279-328.

1996 "The Folly of Trying to Define Truth." Journal of Philosophy 93/6: 263-278.

Eliade, Mircea The Myth of the Eternal Return. Trans. by 1954 Willard Trask. New York: Pantheon Books. 
Franke, Richard W. " More on Geertz's Interpretive Theory." Current 1984 Anthropology 25/5: 692.

Frankenberry, Nancy, and Hans Penner 1999a

$1999 \mathrm{~b}$

Gamwell, Franklin I. 1990 Geertz, Clifford 1972

1973

1980

1985

2000

Habermas, Jürgen 1994

Inglis, Fred 2000

Karatheodoris, Stephen 1988

Kupperman, Joel J. 1999

Lincoln, Bruce 1989
"Geertz's Long-lasting Moods, Motivations, and Metaphysical Conceptions." Journal of Religion 79/4: 617-640.

Language, Truth, and Religious Belief: Studies in Twentieth-Century Theory and Method in Religion. Atlanta: Scholars Press.

The Divine Good. San Francisco: Harper Collins.

"Introduction." In Myth, Symbol, and Culture, ix-xi. Ed. by Clifford Geertz. New York: Norton.

The Interpretation of Cultures. New York: Basic Books.

Negara: The Theatre State in Nineteenth-Century Bali. Princeton: Princeton University Press.

Local Knowledge. New York: Basic Books.

Available Light: Anthropological Reflections on Philosophical Topics. Princeton: Princeton University Press.

Godlove, Terry F. Religion, Interpretation, and Diversity of Belief: 1989 The Framework Model from Kant to Durkheim to Davidson. Cambridge: Cambridge University Press.

Postmetaphysical Thinking. Cambridge, MA: MIT Press.

Clifford Geertz: Culture, Custom and Ethics. Cambridge: Polity Press.

"From Social to Cultural Systems and Beyond: Twenty Years after "Religion as a Cultural System." Soundings 71/1: 53-94.

Learning from Asian Philosophy. Oxford: Oxford University Press.

Discourse and the Construction of Society: Comparative Studies of Myth, Ritual, and Classification. Oxford: Oxford University Press. 
Lovin, Robin $W_{\mathrm{s}}$ and Frank E. Reynolds, eds. 1985

1986 Cosmogony and Religious Ethics: Focus Intro-

1992 "Ethical Naturalism and Indigenous Cultures:

Malinowski, Bronislaw M 1954

Meyer, William J. 1995

Neville, Robert $\mathrm{C}_{\mathrm{n}}$ ed. 2001a

$2001 \mathrm{~b}$

Ogden, Schubert 1975

Ortner, Sherry 1999

Pals, Daniel 1996

Rice, Kenneth A 1980

Schilbrack, Kevin 2002a

$2002 \mathrm{~b}$

2004

Shankman, Paul 1984 duction." Joumal of Religious Ethics 14/1: 48-60. Introduction." Journal of Religious Ethics 20/2: $267-278$.

Cosmogony and Ehical Order. Chicago: University of Chicago Press.

Magi, Scitre, and Religion. New York: Doubleday.

"Private Faith or Public Religion? An Assessment of Habermas's Changing View of Religion." Journal of Religion 75/3: 371-391.

The Human Condition. Albany: State University of New York Press.

Ultimate Realities. Albany: State University of New York Press.

"The Criterion of Metaphysical Truth and the Senses of Metaphysics:" Process Studies 5/1:47-48.

The Fate of "Culture": Geeriz and Beyond. Berkeley: University of California Press.

Seven Theories of Religion. New York: Oxford University Press.

Geertz and Culture. Ann Arbor: University of Michigan Press.

"Myth and Metaphysics." In Thinking through Myths: Philosophical Perspectives, 85-100. Ed. by Kevin Schilbrack. London: Routledge.

"The Study of Religious Beliefs after Davidson ${ }_{\mathrm{r}}$ Method and Theory in the Study of Religion 14/3-4: 335-349.

"Ritual Metaphysics." In Thinking through Rituals: Philosophical Perspectives, 128-147. Ed. by Kevin Schilbrack. London: Routledge.

"The Thick and the Thin: On the Interpretive Theoretical Program of Clifford Geertz" Current Anthropology 25/3: 261-279. 
1985 "Gourmet Anthropology: The Interpretive Menu." Revicw in Anthropology 12/3: 241-248.

Shore, Bradd "An Introduction to the Work of Clifford Geertz." 1988 Soundings 71/1: 15-27.

Stambaugh, Joan The Formles Self Albany: State University of 1999 New York Press.

Sturgeon, Nicholas L. "Naturalism in Ethics." In The Routledge Ency 1997 dopedia of Philosophy 6:713-717. Ed. by Edward Craig, London: Routledge. 